\title{
Tindak Pidana Korupsi Dan Aktivitas Underground Economy
}

\author{
Aloysius Hari Kristianto ${ }^{1}$, \\ Sekolah Tinggi Ilmu Manajemen Shanti Bhuana \\ Pramatatya Resindra Widya ${ }^{2}$, \\ Sekolah Tinggi Ilmu Manajemen Shanti Bhuana
}

\begin{abstract}
Special and continuous attention need to be paid to the phenomenon of underground economic activities, especially in deciding the determination of this economic activities to decrease, monitor, and prevent phenomena that are adverse to national/regional income. The aims of this study are to analyze the activities and the potential for corrupt behavior of the underground economic agents, looking to avoid the tax revenues and implications on interest prices from underground economic activities. The method used for this research is a Explanatory Sequential Mix Methods, first analyzed quantitatively by formulating an equation model and applied using the purposefully selected method. The findings of the study showed that corruptive behavior in the underground economic activities has a positive influence on the amount of money supplied in narrow terms (M1-currency) from the regional levels in the 3T (foremost-outermost-underdeveloped) region. Increased corruption levels can boost the amount of money circulating in society. During most of the higher tax collection, the supply of money will increase (M1). It is necessary to implement pentahelix elements to build a synergy between actors and to begin implementing and mastering electronic/digital systems with E-Government systems in every financial transaction.
\end{abstract}

Keywords: Underground economy; narrow money; tax on revenue; sequential explanatory methods; corruption 


\begin{abstract}
ABSTRAK
Fenomena aktivitas underground economy perlu mendapatkan perhatian secara khusus dan berkesinambungan, terutama dalam menentukan determinasi aktivitas ekonomi untuk mengurangi, mengendalikan, dan menghentikan fenomena yang merugikan pendapatan nasional/daerah. Penelitian ini bertujuan untuk menganalisis dan mengeksplorasi kegiatan pelaku underground economy, potensi perilaku koruptif, penghindaran pembayaran pajak, dan pengaruh aktivitas underground economy terhadap tingkat suku bunga dan tingkat harga. Metode penelitian yang digunakan adalah Explanatory Sequential Mix Methods dengan cara, pertama, menganalisis secara kuantitatif dengan membuat model persamaan, kemudian dilakukan analisis secara kualitatif dengan metode purposefully select. Penelitian ini menganalisis dari tingkat regional daerah 3T (Terdepan-Terluar-Tertinggal), hasil dari penelitian ini menunjukkan bahwa adanya pengaruh positif antara perilaku koruptif terhadap aktivitas underground economy yang ditandai dengan jumlah uang beredar dalam arti sempit (M1-uang kartal), meningkatnya tingkat korupsi dapat meningkatkan jumlah uang beredar dalam masyarakat. Sedangkan semakin tingginya jumlah pajak yang dipungut akan meningkatkan jumlah uang beredar (M1). Perlunya mengimplementasikan unsur pentahelix untuk membentuk sinergi antar pelaku dan mulai untuk mengenalkan dan menguasai sistem elektronik/digital dalam setiap transaksi keuangan dengan sistem e-goverment.
\end{abstract}

Kata Kunci: Underground economy; uang kartal; pajak penghasilan; eksplanatori sekuensial; korupsi

Klasifikasi JEL: D73; H26 


\section{PENDAHULUAN}

Pendapatan nasional merupakan salah satu tolak ukur dalam melihat pertumbuhan ekonomi suatu negara. Dengan pengukuran pendapatan nasional yang tepat, harapannya dapat memberikan kontribusi kepada masyarakat terkait dengan sektor manakah yang memiliki kontribusi terhadap kesejahteraan masyarakat dan sektor apa yang perlu ditingkatkan. Aktivitas underground economy merupakan salah satu bagian yang tidak terpisahkan pada berbagai negara, baik negara maju maupun sedang berkembang. Aktivitas ekonomi tersebut dilakukan secara legal maupun illegal yang tidak terdeteksi pada perhitungan pendapatan nasional atau Pendapatan Domestik Bruto (PDB) (Schneider \& Hametner, 2014). Hasil penelitian Feige (1990) underground economy dibedakan menjadi 4 golongan yaitu; (1) the illegal economy, adalah aktivitas ekonomi yang melanggar undang-undang seperti perdagangan hasil curian, pembajakan, penyelundupan, perjudian, prostitusi dan transaksi narkotika, (2) the unreported economy, adalah tidak adanya pelaporan pendapatan kepada otoritas pajak terkait, (3) the unrecorded economy, adalah tidak adanya pencatatan secara statistik kepada pemerintah terkait hasil pendapatan, dan (4) the informal economy, adalah pelaku ekonomi yang memperoleh pendapatan dengan tidak memiliki izin usaha, perjanjian kerja dan pinjaman dari lembaga keuangan yang resmi (Azwar \& Mulyawan, 2017). Pengukuran tingkat underground economy bukan hal yang mudah dengan tingkat akurasi yang begitu rumit. Perlu adanya kebijakan fiskal yang optimal terkait penarikan pajak, administrasi yang lebih mendukung, dan berpihak pada para pelaku ekonomi ini supaya beralih menjadi pelaku usaha yang bisa tercatat dan memiliki kontribusi terhadap PDB yang dapat mengembangkan sektor Usaha Mikro Kecil Menengah (UMKM) dengan kebijakan subsidi pajak penghasilan (Asaminew, 2010).

Aktivitas underground economy merupakan kegiatan yang menghasilkan pendapatan tanpa diketahui otoritas pajak dengan tujuan penghindaran pajak, yang termasuk didalamnya adalah sektor informal dan black market yang secara umum disebut dengan the parallel market, perlu adanya kebijakan yang berbeda dalam mengimplementasikannya karena kedua pasar tersebut memiliki implikasi yang berbeda. The parallel market terbentuk karena adanya regulasi pemerintah yang terlalu ketat dan pembatasan barang masuk ke dalam pasar. Pasar sektor informal dalam hal produksi bersifat illegal dengan distribusi penjualan dan pangsa pasar yang legal, sedangkan untuk black market proses produksi dan distribusi barang bersifat illegal dan melanggar hukum negara. Gambaran sektor informal adalah unit usaha skala kecil, tenaga kerja mandiri, usaha tidak terdaftar, akses fasilitas kredit minim dan lokasi di daerah perbatasan dan pinggiran (Faal, 2003). Menurut Lofchie (1989) dalam Wardiyanto (2009), kebijakan dalam mengelola pajak sering kali mengalami kegagalan (unsuccessful implementation), permasalahan yang sering muncul disebabkan karena lemahnya kompetensi tenaga ahli, birokrat dan pejabat sipil dalam hal pajak serta munculnya ketidakdisiplinan para pelaku usaha, ketidakpercayaan kepada institusi negara, adanya konflik antara pegawai pemerintahan dengan kelompok masyarkat dominan dan ketidakdisiplinnya pegawai pemerintah sendiri dalam mengimplementasikan komitmen yang telah ditetapkan (Pravasanti, 2018).

Hasil penelitian yang dilakukan oleh Blanchard (2006) menjelaskan bahwa strategi 


\section{1 | Bina Ekonomi}

meningkatkan tarif pajak diharapkan dapat mendorong tingkat penerimaan negara, namun langkah ini dapat menimbulkan potensi deviasi pajak, sehingga dalam melakukan aktivitas ekonomi terjadi adanya disinsentif bagi masyarakat, di lain sisi peningkatan tarif pajak dapat mendorong masyarakat untuk masuk dalam aktivitas underground economy (Azwar \& Mulyawan, 2017). Dengan meningkatnya pertumbuhan underground economy dapat menimbulkan permasalahan dalam hal lemahnya kebijakan desentralisasi fiskal dan rendahnya pendapatan karena kesadaran membayar pajak yang rendah terutama dalam meningkatkan pertumbuhan ekonomi regional per kabupaten (Kanao et al., 2010).

Stigma masyarakat umum terhadap para pelaku underground economy memberikan kesan kumuh, kotor, tidak tertib, serta lokasi yang mereka tempati sebagai sarana berdagang yang kurang teratur dan tertata dengan baik yang sering kali memempati public area tertentu membuat pelaku usaha ini memberikan kesan tidak baik khususnya PKL (Pedagang Kaki Lima). Dari sisi ketenagakerjaan adanya keterbatasan dalam lapangan kerja membuat sektor ekonomi ini terus berkembang dan menjadi pilihan para pelaku underground economy yang hanya bertujuan untuk bertahan hidup. Hal ini yang menjadi penciri sektor underground economy yaitu skala usaha relatif kecil, ketergantungan akan sumber daya lokal, fleksibilitas waktu dan tempat, serta aksesbilitas yang relatif mudah (Herlina wa ode, 2015). Terbentuknya underground economy disebabkan karena adanya beban pajak yang dianggap memberatkan pelaku ekonomi, birokrasi dan larangan yang membebankan, dan perilaku suap yang dapat mengindikasikan tindak korupsi (Tanzi \& Fund, 2014). Adanya korelasi positif antara tingkat korupsi terhadap aktivitas pelaku underground economy yang ditandai dengan jumlah uang beredar dalam arti sempit (uang kartal) jika dilihat dari sisi moneter, peredaran uang kartal yang tidak dapat terukur terhadap perhitungan PDB dapat merugikan pendapatan negara maupun daerah, hal ini perlu menjadi perhatian pemerintah pusat dan daerah. Beban birokrasi yang kompleks membuat para pelaku underground economy lebih memilih jalur alternatif dalam segala urusan dan mencari perlindungan untuk tetap menjalankan usahanya (Ouédraogo, 2017).

Aktivitas kegiatan pelaku underground economy di Indonesia selama ini belum teridentifikasi dan terdefinisikan dengan jelas, perlu adanya kajian secara berkesinambungan untuk menyusun kebijakan yang relevan dengan keadaan yang menyesuaikan dengan kondisi para pelaku ekonomi pada masing-masing daerah di Indonesia. Beberapa estimasi dan pendekatan sudah dilakukan oleh para ekonom di Indonesia guna memperbaiki perhitungan dalam mengukur perkembangan para pelaku ekonomi ini, dengan tujuan kontribusinya terhadap proses pembangunan negara/daerah. Hasil estimasi dengan menggunakan indikator pertumbuhan tingkat konsumsi yang lebih cepat daripada pertumbuhan ekonomi dengan estimasi hasil 40 persen dari nilai PDB, menunjukkan bahwa adanya kegiatan usaha yang tidak membayar pajak, perilaku korupsi, atau usaha yang dilakukan secara terselubung yang tidak terukur dalam salah satu kontributor terhadap PDB (Nizar, 2015).

Hasil penelitian yang dilakukan Faal (2003) melalui pendekatan moneter menjelaskan bahwa nilai underground economy di Guyana tahun 1964 - 2000 dengan tingkat perubahan beban pajak dapat mengubah permintaan uang kartal dengan menambahkan variabel pajak yang 
berpengaruh secara signifikan. Estimasi menunjukkan besarnya underground economy di Guyana dalam periode tersebut sebesar 54,06 persen dari PDB dan rata-rata perkiraan nilai potensi pajak sebesar 19,58 persen dari PDB, semakin tinggi tingkat aktivitas underground economy semakin besar pula potensi pajak yang hilang terhadap rata-rata PDB. Pengukuran besaran underground economy menempatkan variabel permintaan uang kartal-M1 (currency money) hasil adopsi dari model standar permintaan uang milik Tanzi (Samuda, 2016). Tingkat suku bunga deposito secara teori akan berpengaruh negatif terhadap permintaan uang yang berarti bahwa jika terjadi penurunun tingkat permintaan uang maka masyarakat lebih memilih untuk menyimpan dana dalam bentuk depostito (Kristianto, 2019). Namun berbeda ketika masyarakat lebih memilih memutar dana untuk keperluan usaha daripada menyimpan dalam bentuk simpanan dengan asumsi masyarakat, bahwa nilai manfaat lebih tinggi jika dana tersebut dipergunakan untuk usaha meskipun tingkat suku bunga simpanan meningkat (Furuoka \& Munir, 2014).

Penelitian ini bertujuan untuk menganalisis pengaruh dan mengeksplorasi kegiatan pelaku underground economy serta potensi perilaku koruptif dengan pendekatan moneter dan sosial. Variabel bebas yang dipergunakan yaitu tingkat suku bunga, tingkat harga, tingkat penerimaan pajak dan tingkat korupsi sedangkan variabel terikat yaitu jumlah uang beredar uang kartal (M1) yang diformulasikan dalam bentuk persamaan. Penelitian ini mempergunakan Explanatory Sequential Mix Methods dengan menganalisis secara kuantitatif kemudian diperdalam dengan metode kualitatif yang bertujuan untuk mengeksplorasi hasil penelitian terhadap kontribusi untuk kebijakan pemerintah daerah. Dengan ruang lingkup regional perbatasan daerah 3T (TerdepanTerluar-Tertinggal) kabupaten Bengkayang sebagai daerah perbatasan Indonesia - Malaysia. Beberapa kasus korupsi yang terjadi di Kalimantan Barat berdasarkan wilayah, jumlah perkara terus meningkat dari tahun 2006 sebanyak 7 kasus dan 2020 sebanyak 16 kasus (Korupsi, 2019).

\section{METODE DAN DATA}

Potensi jumlah peningkatan penerimaan negara/pajak yang hilang dapat disebabkan karena makin berkembangnya aktivitas underground economy suatu negara. Hal ini dapat disebabkan karena tidak optimalnya pengawasan dari otoritas pajak. Tingginya tingkat aktivitas ekonomi ini salah satunya adalah jumlah pajak yang harus dibayar kepada negara (Tanzi \& Fund, 2014). Adanya hubungan positif antara perubahan harga dengan aktivitas underground economy, semakin tinggi aktivitas ini maka akan ada potensi peningkatan harga. Hubungan ini tergantung dari independensi Bank Indonesia sebagai bank sentral dalam menentukan kebijakan moneter yang akan diterapkan (Mazhar \& Méon, 2017). Studi empiris yang dilakukan oleh Williams \& Horodnic (2017) menunjukkan bahwa kompleksitas birokrasi, tingginya pembayaran pajak, dan tingginya tingkat korupsi antar pejabat sektor publik menyebabkan adanya peralihan segmen aktivitas ekonomi dari ekonomi formal beralih ke aktivitas underground economy. Hasil penelitian yang dilakukan oleh Kiani et al (2015) dengan metode campuran menunjukkan bahwa hasil penelitian di Pakistan, secara jangka panjang aktivitas underground economy menciptakan tingginya tingkat peredaran uang, dengan indikator moneter tingkat suku bunga simpanan, berpengaruh negatif terhadap permutaran uang kartal. Sedangkan tingkat harga berpengaruh 
positif terhadap permintaan/peredaran uang kartal masyarakat Pakistan dengan periode waktu 1975-2010. Berdasarkan beberapa hasil studi empiris terdahulu, maka perumusan hipotesis dalam penelitian ini adalah sebagai berikut:

Hasil studi yang dilakukan oleh Amoh \& Adafula (2019), tingginya perubahan harga, menciptakan peningkatan aktivitas underground economy serta lemahnya lembaga pemerintah dalam mengatasi aktivitas ekonomi ini. Hasil penelitian Samuda (2016) menjelaskan bahwa tingkat harga berpengaruh positif terhadap permintaan uang oleh pelaku underground economy hal tersebut dikaitkan dengan perubahan harga barang yang berpengaruh terhadap daya beli masyarakat.

H1 : Tingkat harga berpengaruh posistif terhadap aktivitas underground economy.

Hasil penelitian Melnick \& Sokoler (1984) menyimpulkan bahwa perubahan pada pajak dapat mendorong kebijakan untuk meningkatkan jumlah uang beredar yang bertujuan untuk mengurangi output dan meningkatkan harga, dengan meningkatkan jumlah pajak pemerintah dapat mengalokasikannya dalam bentuk kredit kepada masyarakat. Studi empriris yang dilakukan oleh Nurunnabi (2019) menyatakan bahwa pentingnya sosialisasi dan edukasi kepada masyarakat akan pajak bagi negara, dengan makin kurang sadarnya masyarakat akan pajak maka kontribusi terhadap pembangunan akan sangat minim. Hal ini juga bertujuan untuk menekan aktivitas pelaku underground economy.

H2 : Pajak penghasilan berpengaruh positif terhadap aktivitas underground economy.

Hasil penelitian Samuda, (2016) menjelaskan bahwa suku bunga simpanan merupakan opportunity cost dari memegang uang yang berpengaruh secara negatif terhadap aktivitas pelaku underground economy, dengan asumsi jika suku bunga simpanan naik, harapannya masyarakat lebih berminat untuk menyimpan uangnya dalam bentuk deposito. Hasil studi yang dilakukan oleh Afdi \& Purnomo, (2015) menurunnya permintaan uang tunai dalam masyarakat merupakan hasil dari berkembangnya sistem keuangan di Indonesia dalam hal ini adalah fasilitas perbankan yang ditawarkan seperti akses ATM, mobile banking, dan internet banking.

H3 : Tingkat suku bunga simpanan deposito 1 bulanan berpengaruh negatif terhadap aktivitas underground economy

Hasil penelitian yang dilakukan oleh Rahmani \& Yousefi (2010) secara makro ekonomi, tingginya tingkat korupsi sangat berpotensi meningkatkan jumlah uang beredar dalam masyarakat terhadap aktivitas pelaku underground economy baik untuk negara maju maupun berkembang. Hasil penelitian Ozsahin \& Ucler (2017) menyimpulkan bahwa potensi peningkatan korupsi dengan regulasi yang lemah dapat menciptakan inflasi, hal ini bisa secara sengaja dilakukan dengan menambah jumlah uang beredar dalam masyarakat untuk mencari keuntungan dari oknum pejabat.

H4 : Tingkat korupsi berpengaruh positif terhadap aktivitas underground economy 
Adapaun kerangka pemikiran dengan pendekatan Explanatory Sequential Mix Methods dapat dilihat pada gambar dibawah ini:

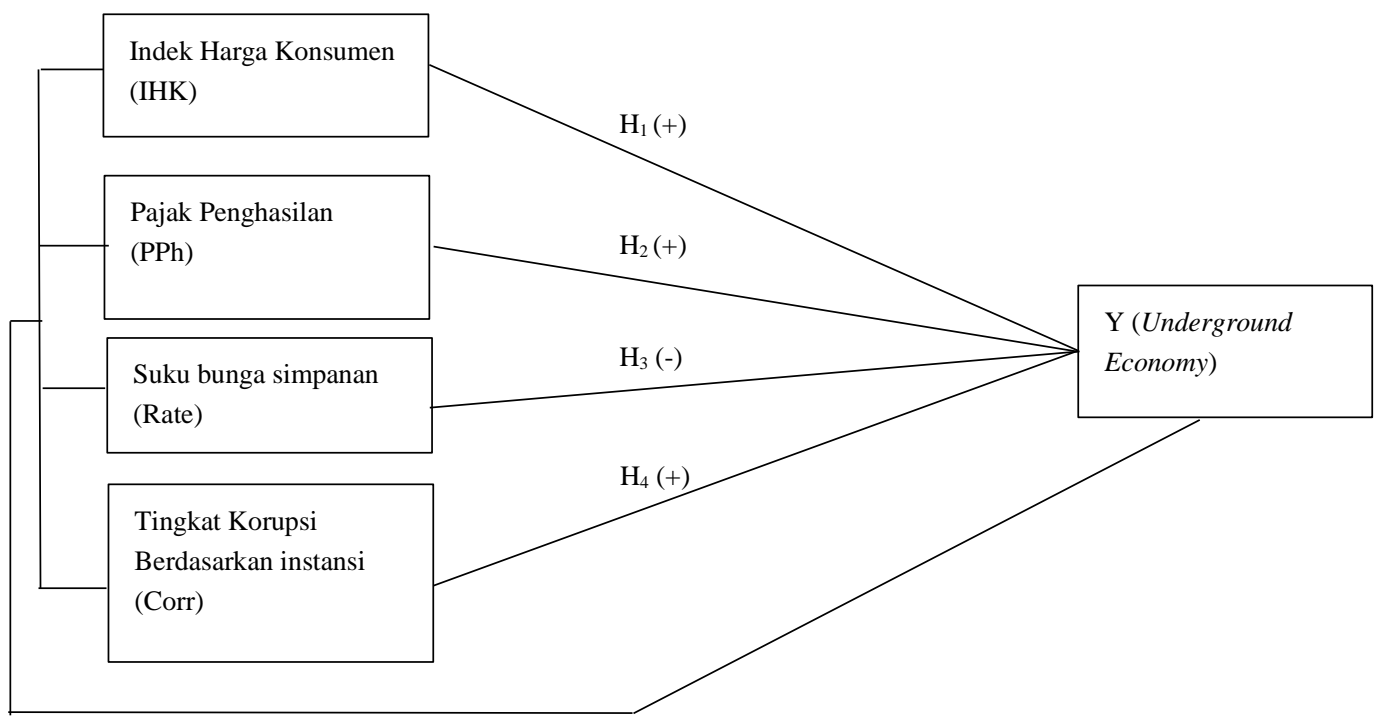

Gambar 1. Kerangka Pemikiran

Penelitian ini menggunakan pendekatan Exlanatory Sequential Mix Methods dengan menggabungkan metode penelitian kuantitatif dan metode kualitatif secara berurutan, metode kuantatif dipergunakan untuk pengukuran yang bersifat deskriptif, komparatif, dan asosiatif sedangkan metode kualitatif berperan untuk pembuktian, pendalaman, perluasan, perlemahan atau pengguguran data kuantitatif yang diperoleh pada tahap awal (Creswell, 2010). Penjelasan Explanatory Sequential Mix Methods tersebut dapat dilihat pada gambar 2 berikut ini.

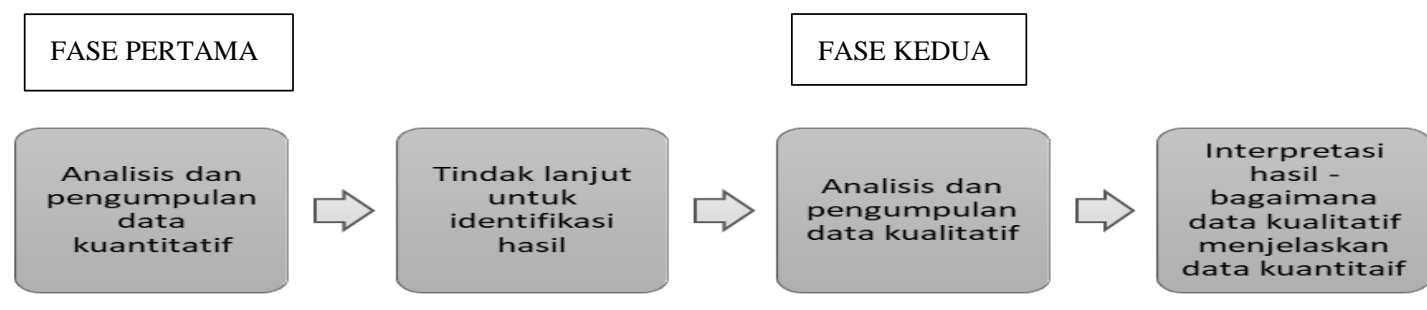

Gambar 2. Pendekatan Explanatory Sequential Mix Methods

Fase pertama dengan menggunakan metode kuantitatif dibentuk model persamaan guna mengukur dan menyusun hipotesis kemudian hasil perhitungan secara statistik dengan menggunakan analisis regresi linear berganda metode OLS (Ordinary Least Square) dengan jenis data sekunder time series dengan hasil estimasi yang bersifat BLUE (Best Linear Unbias Estimator) dengan tujuan mendekatkan garis regresi terhadap data aktual (Basuki, 2017). Fase kedua di perdalam kembali dengan metode kualitatif, dengan teknik indept interview, observasi partisipatif 
dan dokumentasi, dengan penentuan obyek penelitian secara purposefully select dimana peneliti mengidentifikasi lokasi dan individu/kelompok (4-6 orang/kelompok) dengan sengaja dan terencana (Creswell, 2014). Persamaan awal dengan asumsi hasil BLUE dengan bentuk fungsi dapat diartikan sebagai berikut:

$$
M 1_{i}=f(I H K, P P h, \text { Rate }, \text { Corr }) \cdot C p
$$

Asumsi hasil Best Linear Unbias Estimator (BEST) dari nilai harapan (expected value) sebagai berikut:

$$
E\left(M 1_{i} I H K, P P h, \text { Rate, Corr }\right)=\beta_{0}+\beta_{1} I H K_{i}+\beta_{3} P P h_{i}-\beta_{3} \text { Rate }_{i}+\beta_{3} \operatorname{Corr}_{i}+\varepsilon_{i} 2
$$

Model persamaan dapat dirumuskan sebagai berikut:

$$
M 1_{i}=\beta_{0}+\beta_{1} I_{H} K_{i}+\beta_{2} P P h_{i}-\beta_{3} \text { Rate }_{i}+\beta_{4} \operatorname{Corr}_{i}+\varepsilon_{i}
$$

Residual model dapat dinyatakan dalam persamaan berikut:

$$
\begin{aligned}
& \varepsilon_{i}=M 1_{i}-M 1^{\wedge}{ }_{i} \\
& \varepsilon_{i}=M 1_{i}-\beta_{1} I H K_{i}-\beta_{2} P P h_{i}+\beta_{3} \text { Rate }_{i}-\beta_{4} \operatorname{Corr}_{i}
\end{aligned}
$$

Persamaan 3 memberi asumsi bahwa dari pendekatan moneter yang ditandai dengan Indeks Harga Konsumen, tingkat suku bunga simpanan, dan pajak penghasilan berpengaruh terhadap

\begin{tabular}{|c|c|}
\hline Variabel Penelitian & Keterangan \\
\hline M1 & $\begin{array}{l}\text { Permintaan uang riil M1 - Uang Kartal sebagai variabel yang } \\
\text { mewakili aktivitas underground economy yang terdiri dari } \\
\text { uang logam dan uang kertas sebagai sarana transaksi dalam } \\
\text { masyarakat. }\end{array}$ \\
\hline IHK & $\begin{array}{l}\text { Indeks Harga Konsumen menunjukkan pertumbuhan tingkat } \\
\text { harga dalam masyarakat sebagai kekuatan daya beli, dengan } \\
\text { asumsi berpengaruh positif terhadap permintaan uang } \\
\text { kartal. }\end{array}$ \\
\hline $\mathrm{PPh}$ & $\begin{array}{l}\text { Pajak penghasilan sebagai penentu penerimaan untuk } \\
\text { negara dengan asumsi berpengaruh postif terhadap } \\
\text { permintaan uang kartal. }\end{array}$ \\
\hline & $\begin{array}{l}\text { Tingkat suku bunga deposito } 1 \text { bulanan di ukur sebagai } \\
\text { opportuninty cost masyarakat memegang uang, dengan }\end{array}$ \\
\hline
\end{tabular}
permintaan uang kartal yang mewakili aktivitas underground economy. Sedangkan tingkat korupsi berpengaruh positif terhadap aktivitas underground economy, dimana kenaikan tingkat korupsi meningkatkan aktivitas underground economy.

Tabel 1. Definisi Operasional Variabel 
Rate asumsi berpengaruh negatif terhadap permintaan uang kartal.

Tingkat korupsi bersifat politis dan birokrasi yang dapat

Corr menghasilkan pendapatan tinggi, dengan mendistorsi beberapa harga investasi publik sebagai pembayaran suap kepada oknum pejabat, dengan asumsi perpengaruh positif terhadap aktivitas underground economy.

\section{PEMBAHASAN}

Bagian ini menjelaskan mengenai hasil analisis yang dilakukan, baik secara kuantitatif maupun secara kualitatif untuk menjawab tujuan penelitian yang telah diajukan. Hasil analisis yang telah dilakukan dijelaskan sebagai berikut:

\subsection{Statistik Deskriptif}

Pada statistik deskriptif menjelaskan mengenai kondisi variabel penelitian, yang terdiri dari jumlah uang beredar M1-uang kartal, indeks harga konsumen, suku bunga pinjaman, jumlah kasus korupsi dalam instansi, dan penerimaan pajak.

Selama tahun 2010 hingga 2019 jumlah uang beredar di tangan masyarakat berupa uang kartal dan uang giral mengalami pertumbuhan yang positif. Data tersebut menunjukkan bahwa terjadi peningkatan yang cukup besar dari Rp577.432 trilyun pada tahun 2010 menjadi Rp1.540.867 trilyun pada tahun 2019. Kondisi demikian terjadi karena adanya peningkatan aktiva baik dalam negeri maupun luar negeri. Selain itu faktor lain yang dapat mendukung peningkatan jumlah uang beredar adalah peningkatan jumlah penyaluran kredit perbankan dapat dilihat pada Gambar 3 (Lawi, 2019).

Nilai indeks harga konsumen mengalami nilai tertinggi pada tahun 2013 mencapai 3,26 persen. Pada tahun berikutnya nilai indeks harga konsumen mengalami penurunan hingga menjadi 1,13 persen pada tahun 2019 (Departemen Statistik Bank Indonesia, 2019). Berdasarkan berita dari BBC Indonesia, kondisi demikian terjadi karena peningkatan harga pada bahan pangan akibat gangguan pasokan dan Bahan Bakar Minyak (BBM). Dilain sisi pada tingkat suku bunga deposito bulanan menunjukkan nilai di kisaran 1,71 persen hingga 2,14 persen yang merupakan nilai suku bunga deposito tertinggi pada tahun 2014. Kondisi demikian terjadi salah satunya dikarenakan adanya tekanan dari pihak pemilik dana besar perbankan yang menginginkan tingkat pengembalian yang tinggi (Fathul, 2014). Kemudian pada tahun 2015 hingga tahun 2019 tingkat suku bunga mengalami penurunan karena suku bunga acuan yang juga mengalami penurunan, dapat dilihat pada Gambar 4 dibawah ini. 


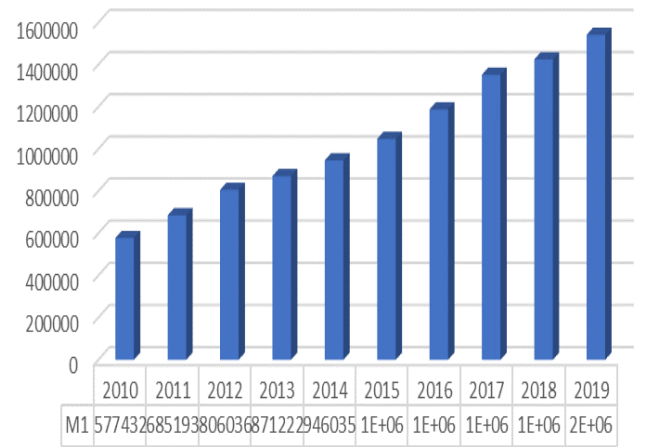

Sumber: Bank Indonesia (2019)

Gambar 3. Jumlah Uang Beredar Periode 2010 hingga 2019

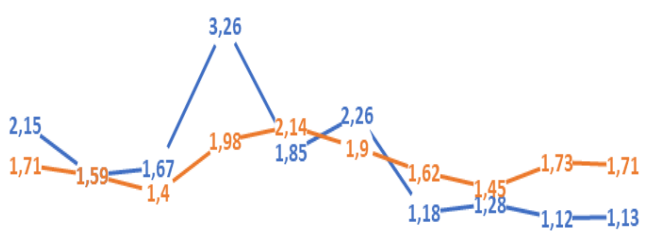

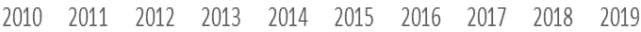

- - HK - - Interest rate

Sumber: Bank Indonesia (2019)

Gambar 4. Perkembangan Indeks Harga Konsumen dan Tingkat Suku Pinjaman Periode 2010 hingga 2019

Jumlah tindak korupsi berdasarkan instansi yang terjadi di Indonesia selama tahun 2010 hingga 2019. Tahun 2018 menjadi tahun dengan jumlah temuan kasus korupsi tertinggi sebesar 50 kasus. Menurut Alamsyah \& Surnayanto (2018) yang melakukan pemetaan tindakan korupsi berdasarkan lembaga, menjelaskan bahwa pemerintah daerah dan pemerintah desa menjadi lembaga dengan tindak korupsi yang menyebabkan kerugian pada negara senilai Rp 833 miliar dan Rp 1,2 trilyun. Hal ini menjelaskan bahwa pemerintah daerah dan pemerintah desa menjadi lembaga dengan jumlah tindakan korupsi dan menyebabkan kerugian negara tertinggi sepanjang tahun 2018, hal ini dapat ditinjau pada Gambar 5 (Alamsyah et al., 2018).

Jumlah penerimaan pajak negara mengalami peningkatan dari tahun 2010 hingga 2019. Terjadinya peningkatan penerimaan pajak salah satunya dikarenakan adanya kebijakan pengampunan pajak (tax amnesty). Selain itu, penerimaan pajak yang tinggi dikarenakan adanya peningkatan penerimaan pajak penghasilan $(\mathrm{PPh})$, hal ini dapat ditinjau pada Gambar 6 (Kementerian Keuangan Republik Indonesia, 2019).

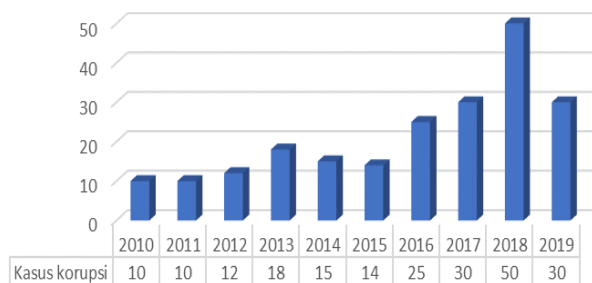

Sumber: Korupsi (2019)

Gambar 5. Tindak Korupsi Berdasarkan Instansi Periode 2010 hingga 2019

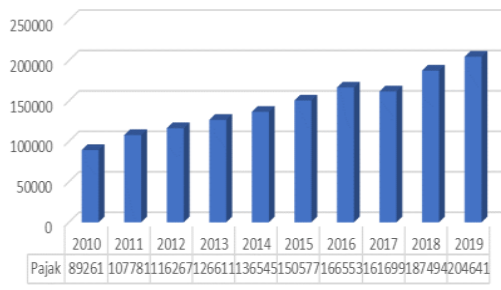

Sumber: pajak.go.id (2019)

Gambar 6. Perkembangan Penerimaan Pajak Periode Tahun 2010 hingga 2019 


\subsection{Analisis Kuantitatif}

Analisis kuantitatif dilakukan dengan tujuan untuk mengetahui pengaruh indeks harga konsumen (IHK), pajak penghasilan (PPh), suku bunga simpanan deposito 1 bulanan (Rate), dan tingkat korupsi yang terjadi (Corr) terhadap jumlah uang beredar (M1). Analisis kuantitatif dilakukan menggunakan Ordinary Least Square (OLS) dengan bantuan alat statistik berupa Eviews 8.

Uji asumsi klasik yang dilakukan terdiri dari empat, yaitu uji normalitas, heterokedastisitas, multikolinieritas, dan autokorelasi. Uji asumsi klasik dilakukan dengan tujuan untuk membuktikan bahwa model yang dibangun merupakan model yang BLUE (Best Linier Unbiased Estimator).

Uji asumsi normalitas bertujuan untuk mengetahui distribusi data yang diteliti. Pengujian asumsi normalitas menggunakan Jarquee Berra yang ditunjukkan pada gambar 7. Hasil pengujian menunjukkan bahwa nilai Jarquee Berra probability adalah sebesar 0,553271 (> critical value 5\%) sehingga dapat dikatakan bahwa data yang diteliti memiliki distribusi yang normal.
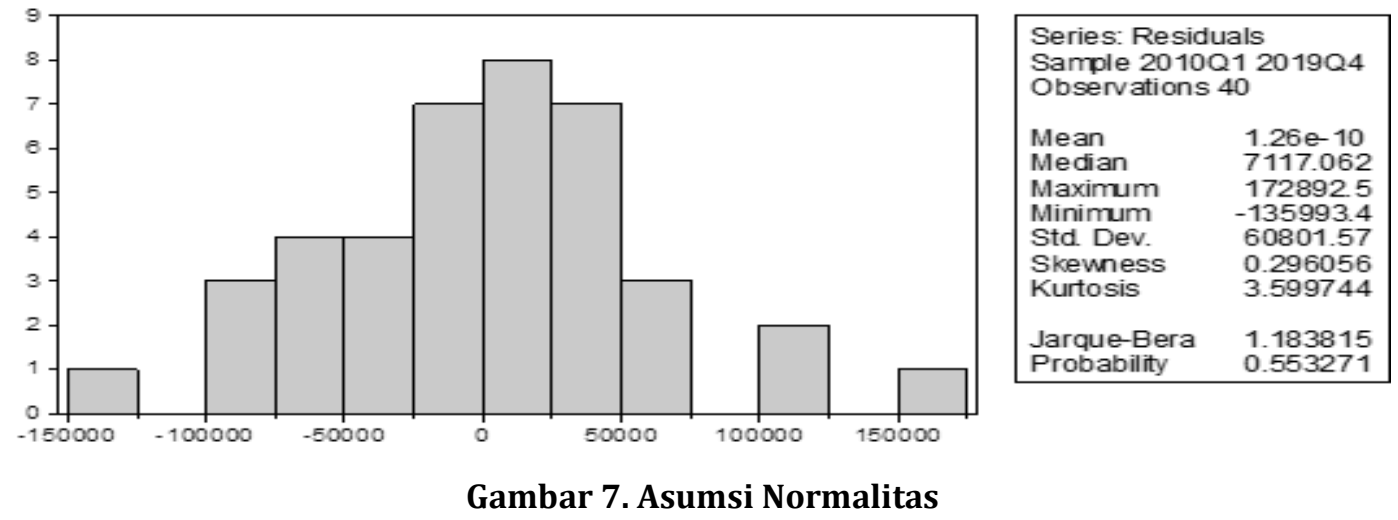

Uji asumsi heterokedastisitas bertujuan untuk mengetahui adanya varian residual yang bersifat tidak sama untuk semua pengamatan dalam model regresi. Pengujian asumsi heterokedastisitas menggunakan Glejser test yang ditunjukkan pada tabel 2. Hasil penelitian menunjukkan bahwa nilai signifikansi adalah sebesar 0,3209 (> critical value 5\%) sehingga dapat dikatakan bahwa varian residual semua pengamatan dalam model regresi bersifat homogen.

Tabel 2. Hasil Asumsi Heterokedastisitas

Heteroskedasticity Test: Glejser

\begin{tabular}{llll}
\hline \hline F-statistic & 1.161371 & Prob. F(4,35) & 0.3445 \\
Obs*R-squared & 4.687025 & Prob. Chi-Square(4) & 0.3209 \\
Scaled explained SS & 4.545054 & Prob. Chi-Square(4) & 0.3372 \\
\hline \hline
\end{tabular}

Keterangan: signifikansi 5\%. 
Uji asumsi multikolinieritas bertujuan untuk mengetahui adanya korelasi antar variabel bebas yang digunakan dalam model regresi. Pengujian asumsi multikolinieritas menggunakan nilai variance inflation factor (VIF) yang ditunjukkan pada tabel 3. Nilai VIF yang ditunjukkan adalah dari suku bunga simpanan deposito sebesar 1,610334, IHK sebesar 2,200178, tingkat korupsi sebesar 3,261550, dan PPh sebesar 3,144188, keempat nilai VIF yang ditunjukkan kurang dari $(<)$ 10, sehingga dapat dikatakan bahwa tidak terdapat korelasi yang kuat pada setiap variabel bebas yang digunakan dalam model regresi.

Tabel 3. Hasil Asumsi Multikolinieritas

Variance Inflation Factors

Date: 07/05/20 Time: 07:12

Sample: 2010Q1 2019Q4

Included observations: 40

\begin{tabular}{cccc}
\hline \hline Variable & $\begin{array}{c}\text { Coefficient } \\
\text { Variance }\end{array}$ & $\begin{array}{c}\text { Uncentered } \\
\text { VIF }\end{array}$ & $\begin{array}{c}\text { Centered } \\
\text { VIF }\end{array}$ \\
\hline \hline C & $8.45 \mathrm{E}+09$ & 82.09533 & NA \\
IR & $3.46 \mathrm{E}+09$ & 101.4546 & 1.610334 \\
IHK & $5.04 \mathrm{E}+08$ & 17.73845 & 2.200178 \\
CORR & 2341638. & 13.67468 & 3.261550 \\
PPH & 0.272927 & 58.66736 & 3.144188 \\
\hline \hline
\end{tabular}

Keterangan: signifikan

Uji asumsi autokorelasi bertujuan untuk mengetahui adanya korelasi variabel dalam model regresi dengan perubahan waktu. Pengujian asumsi autokorelasi menggunakan Durbin Watson test, jika nilai berada di antara -2 dan +2 maka dapat dinyatakan tidak terdapat gejala autokorelasi (Kristianto \& Nurchayo, 2020). Hasil penelitian menunjukkan bahwa durbin watson stat adalah sebesar 1,549612 yang berada di antara nilai -2 dan +2 sehingga dapat dikatakan bahwa tidak terdapat korelasi antara variabel dalam model regresi dengan perubahan waktu atau tidak terdapat gejala autokorelasi.

Secara keseluruhan hasil uji asumsi klasik menjelaskan bahwa model regresi yang digunakan telah memenuhi setiap asumsi klasik, yang terdiri dari asumsi normalitas, asumsi heterokedastisitas, asumsi multikolinieritas, dan asumsi autokorelasi. Oleh karena itu model regresi dapat dilanjutkan untuk uji hipotesis menggunakan Ordinary Least Square.

Hasil uji hipotesis yang dilakukan pada penelitian ini dijelaskan melalui Tabel 4 berikut.

Tabel 4. Hasil Ordinary Least Square

\begin{tabular}{ccccc} 
Variable & Coefficient & Std. Error & t-Statistic & Prob. \\
\hline \hline C & -73398.49 & 91948.00 & -0.798261 & 0.4301 \\
RATE & -89061.47 & 58851.76 & -1.513319 & 0.1392
\end{tabular}




\begin{tabular}{lrlll}
\multicolumn{1}{c}{ IHK } & 12320.62 & 22451.10 & 0.548776 & 0.5866 \\
\multicolumn{1}{c}{ CORR } & 3832.358 & 1530.241 & 2.504415 & 0.0171 \\
PPH & 7.734766 & 0.522424 & 14.80554 & 0.0000 \\
\hline \hline R-squared & 0.961859 & Mean dependent var & 996665.9 \\
Adjusted R-squared & 0.957500 & S.D. dependent var & 311329.6 \\
S.E. of regression & 64181.97 & Akaike info criterion & 25.09330 \\
Sum squared resid & $1.44 \mathrm{E}+11$ & Schwarz criterion & 25.30441 \\
Log likelihood & -496.8660 & Hannan-Quinn criter. & 25.16963 \\
F-statistic & 220.6638 & Durbin-Watson stat & 1.549612 \\
Prob(F-statistic) & 0.000000 & & \\
\hline \hline
\end{tabular}

Keterangan: signifikansi 5\%.

Hasil penelitian menunjukkan bahwa tingkat suku bunga deposito tidak dapat dibuktikan berpengaruh (prob= 0,1392 > critical value $5 \%$ ) terhadap jumlah uang beredar (M1). Hasil penelitian ini menunjukkan bahwa perubahan jumlah uang yang beredar di masyarakat (M1) tidak dapat dibuktikan dipengaruhi oleh tingkat suku bunga deposito. Hasil penelitian juga menunjukkan bahwa indeks harga konsumen tidak dapat dibuktikan berpengaruh (prob=0,5866 > critical value $5 \%$ ) pada jumlah uang yang beredar di masyarakat (M1).

Hasil pada Tabel 4 menunjukkan bahwa tingkat korupsi (corr) memiliki pengaruh yang positif $($ coefficient $=3832,358)$ signifikan $(0,0171<$ critical value $5 \%)$ terhadap jumlah uang beredar (M1). Jumlah uang beredar (M1) sendiri menunjukkan jumlah uang kartal (baik logam maupun kertas yang dipegang oleh masyarakat) dan uang giral yang berupa surat berharga dengan mata uang rupiah. Hasil penelitian menunjukkan bahwa peningkatan jumlah kasus korupsi yang terjadi di instansi dapat mempengaruhi peningkatan jumlah uang beredar (M1). Sebaliknya, jika terdapat penurunan jumlah kasus korupsi maka dapat mempengaruhi penurunan jumlah uang beredar (M1).

Hasil ini mendukung hasil penelitian dari Rahmani \& Yousefi (2010) yang menjelaskan bahwa tingkat korupsi menjadi salah satu faktor penting dalam menentukan pertumbuhan jumlah uang beredar. Negara yang memiliki pengendalian kasus korupsi yang lebih baik dapat mendukung penurunan inflasi menjadi lebih rendah, hal ini dikarenakan terjadi efisiensi pada kebijakan moneter sebuah negara yang menciptakan pendapatan negara yang lebih baik sehingga bank sentral tidak perlu melakukan kebijakan meningkatkan jumlah uang beredar (Samimi \& Abedini, 2012).

Negara dengan tingkat korupsi yang rendah menunjukkan jumlah uang beredar yang rendah, sedangkan negara dengan tingkat korupsi yang tinggi justru menunjukkan jumlah uang beredar yang lebih besar. Kondisi demikian dapat terjadi karena tingginya jumlah kasus korupsi yang terjadi pada sebuah negara menyebabkan pengeluaran pemerintah dan defisit anggaran meningkat. Dalam kondisi seperti ini, bank sentral dalam sebuah negara akan melakukan kebijakan untuk mencetak uang untuk membiayai defisit anggaran yang terjadi yang menyebabkan pertumbuhan pada jumlah uang beredar. Lebih lanjut dijelaskan bahwa pertumbuhan jumlah uang yang beredar dapat meningkatkan risiko terjadinya inflasi yang lebih tinggi pada negara yang bersangkutan (Rahmani \& Yousefi, 2010). 


\section{1 | Bina Ekonomi}

Tingkat korupsi yang terjadi dapat meningkatkan inflasi salah satunya karena sistem pajak yang berlaku dalam sebuah negara tidak efisien sehingga tidak dapat melakukan kompensasi atas pendapatan yang hilang dan kemudian memilih kebijakan seigniorage, yaitu mencari keuntungan dengan meningkatkan pertumbuhan jumlah uang beredar untuk menciptakan inflasi (Ozsahin \& Ucler, 2017).

Hasil penelitian juga menunjukkan bahwa besarnya jumlah pajak penghasilan berpengaruh positif (coefficient $=7,734766)$ signifikan $(0,0000<$ critical value $5 \%$ ) terhadap jumlah uang beredar (M1). Hasil ini menjelaskan bahwa peningkatan jumlah pajak penghasilan yang dapat dipungut dapat mempengaruhi peningkatan jumlah uang beredar yang dipegang oleh masyarakat. Sebaliknya penurunan jumlah pajak penghasilan yang berhasil dipungut dapat mempengaruhi penurunan jumlah uang beredar yang dipegang oleh masyarakat.

Hasil penelitian yang dilakukan sejalan dengan hasil penelitian yang dilakukan oleh Musa, Usman, dan Zoramawa (2014) yang menjelaskan hubungan pendapatan pemerintah dengan money supply di Nigeria. Semakin tinggi pendapatan pemerintah maka semakin besar jumlah money supply di Nigeria. Tingginya pendapatan pemerintah salah satunya dikarenakan semakin besarnya jumlah pajak penghasilan yang dapat dipungut oleh pemerintah (Yakubu et al., 2014).

Hasil penelitian yang dilakukan juga mendukung pernyataan dari Contc et al. (1984) yang menyatakan bahwa perubahan pada tingkat pajak dapat mendorong kebijakan untuk meningkatkan jumlah uang beredar yang bertujuan untuk mengurangi output dan meningkatkan harga. Hal ini juga dijelaskan oleh Melnick \& Sokoler (1984) bahwa pemerintah akan berusaha untuk mempertahankan pendapatan, termasuk dalam pendapatan yang diperoleh dari pajak melalui kebijakan meningkatkan jumlah uang beredar melalui kemudahan kredit.

Hasil penelitian juga menjelaskan bahwa secara komprehensif atau simultan terdapat pengaruh yang signifikan dari tingkat suku bunga deposito (RATE), indeks harga konsumen (IHK), jumlah kasus korupsi (Corr), dan besarnya jumlah pajak penghasilan (PPh) terhadap jumlah uang beredar (M1). Hasil ini menjelaskan bahwa perubahan yang terjadi pada suku bunga deposito (RATE), indeks harga konsumen (IHK), jumlah kasus korupsi (Corr), dan besarnya jumlah pajak penghasilan (PPh) secara bersama atau dalam kurun waktu yang bersama dapat memberikan pengaruh terhadap jumlah uang beredar (M1) di masyarakat.

\subsection{Analisis Kualitatif}

Analisis kualitatif dilakukan untuk menjelaskan peran pelaku underground economy terhadap perekonomian regional daerah 3T, yaitu terdepan, terluar, dan tertinggal. Underground economy sendiri merupakan segala bentuk aktivitas ekonomi yang tidak terdaftar dan tidak berkontribusi terhadap pembentukan produk nasional bruto (Badulescu, 2011). Underground economy dapat diklasifikasikan menjadi empat, yaitu illegal economy, unreported economy, unrecorded economy, dan informal economy. Illegal economy merupakan aktivitas ekonomi yang melanggar atau bertentangan dengan peraturan hukum yang berlaku, kemudian unreported economy merupakan aktivitas ekonomi yang pendapatan yang diperolehnya tidak dilaporkan kepada otoritas pajak, unrecorded economy merupakan aktivitas ekonomi yang seharusnya tercatat namun tidak tercatat dalam statistik pemerintah, informal economy adalah aktivitas ekonomi yang 
para pelaku ekonominya sebagian besar tidak memiliki izin resmi dari pihak yang berwenang (Feige, 1990).

Berkaitan dengan peran underground economy terhadap perekonomian regional daerah 3T, dalam penelitian ini dilakukan wawancara dengan para pelaku underground economy yang terdiri dari toko kelontong, pedagang kaki lima (PKL), warung kopi, dan penjual minuman keras yang diwakilkan oleh dua orang pelaku usaha. Hasil wawancara menunjukkan alasan sebagian besar informan membuka usaha adalah untuk menyambung hidup, artinya masyarakat melakukan usaha toko kelontong, pedagang kaki lima, warung kopi, dan penjual minuman keras dengan tujuan untuk memenuhi kebutuhan hidup. Hasil penelitian juga menerangkan bahwa jam kerja yang diberlakukan melebihi peraturan yang berlaku yaitu lebih dari 8 jam kerja per hari. Hal ini menunjukkan bahwa usaha yang dijalankan oleh informan merupakan usaha yang tidak mematuhi peraturan yang berlaku, khususnya berkaitan dengan waktu kerja yang telah ditetapkan.

Berkaitan dengan izin usaha, semua informan pelaku usaha toko kelontong, pedagang kaki lima, warung kopi, dan penjual minuman keras tidak memiliki NPWP ataupun jaminan sosial. Terdapat beberapa alasan yang diungkapkan oleh informan terkait tidak memiliki NPWP dan jaminan sosial untuk usahanya, sebagaimana dijelaskan oleh pelaku usaha toko kelontong berikut:

"Tidak ada sosialisasi masalah NPWP dan izin usaha dari pemerintah - perlu adanya sosialisasi terkait NPWP dan Izin Usaha serta manfaat dr pajak tersebut dan pemahaman mengenai $N P W P^{\prime \prime}$ (Pelaku usaha toko kelontong 1).

Alasan berikutnya karena merasa tidak ada dampak dari memiliki NPWP atas usaha yang dilakukan sehingga tidak merasa perlu memiliki NPWP, sebagaimana dijelaskan pada pernyataan berikut.

"NPWP dirasa tidak perlu atau dibutuhkan, karena tidak ada manfaat dan selama ini merasa usaha melanggar hukum, usaha tidak tetap" (Pelaku usaha toko kelontong 2).

"NPWP Tidak begitu penting dan bermanfaat" (Pedagang kaki lima 1).

"NPWP dan izin usaha tidak diperlukan karena merasa usaha kecil dan tidak diperhitungkan, merupakan usaha sampingan aparat dan anggota dewan" (Pelaku usaha Warung Kopi 1).

Alasan lain yang dinyatakan oleh pelaku usaha yang tidak mau memiliki NPWP adalah birokrasi yang rumit dan panjang. Hal ini disampaikan oleh salah satu pelaku usaha berikut.

"Izin usaha tidak ada karena dirasa rumit dan birokrasi dalam pengurusan panjang" (Pelaku usaha warung kopi 2).

Bagi pelaku usaha, memiliki NPWP atas nama usaha yang dijalankan menjadi salah satu unsur yang menyatakan bahwa usaha yang dijalankan dapat dikatakan sebagai usaha yang legal. Namun kondisi tidak adanya sosialisasi atas pentingnya NPWP bagi usaha, pelaku usaha yang merasa rumit untuk memperoleh NPWP dan menganggap NPWP tidak penting untuk dimiliki menyebabkan pelaku usaha tetap berada dalam underground economy. Alasan tersebut juga telah diungkapkan 
dalam penelitian Rothenberg et al. (2016) yang melakukan penelitian mengenai sektor informal ekonomi di Indonesia, bahwa pelaku usaha sektor informal ataupun underground economy akan tetap berada dalam kondisi ilegal karena tidak merasakan kerugian atas status ilegal dari usaha yang dilakukan.

Pada dasarnya underground economy yang dilakukan oleh para pelaku usaha ini dapat menjadi beban terhadap perekonomian regional maupun perekonomian secara nasional. Pelaku usaha underground economy tidak memiliki kemampuan ataupun pengetahuan yang cukup untuk dapat mendaftarkan secara legal usaha yang dilakukan ke otoritas pajak, sehingga hal ini berdampak buruk bagi pendapatan pajak negara, yang seharusnya memiliki potensi untuk dipungut namun tidak dapat dipungut karena tidak adanya NPWP dan data yang jelas tentang usaha yang dijalankan oleh pelaku usaha underground economy. Hal ini juga dijelaskan oleh Rothenberg et al., (2016), bahwa kehadiran pelaku usaha informal sektor yang juga termasuk dalam underground economy dapat berdampak buruk pada pendapatan pajak, struktur pasar, dan persaingan.

Berkaitan dengan kontribusi secara ekonomi, menurut pengakuan informan penelitian para pelaku usaha underground economy ini melakukan pembayaran iuran untuk dapat melancarkan usaha yang dilakukan. Iuran yang dimaksud berupa iuran kebersihan dan keamanan. Namun menurut pengakuan beberapa informan, iuran tersebut merupakan iuran sukarela yang diperuntukkan pribadi dan bukan kepada pihak dinas yang terkait. Hal ini diungkapkan dalam pernyataan berikut.

"Adapun iuran yang diberi adalah iuran sukarela, tanpa adanya paksaan dari pihak Yang bersangkutan, Dan iuran yang diberikan diperuntukkan pribadi bukan untuk dinas, biasa pelaku usaha memberikan uang keamanan berkisar 200-300 ribu per orang. Pemberian iuran tersebut setiap bulan di mana pihak keamanan yang datang berkisar dua sampai tiga orang" (Pelaku usaha warung kopi 1).

"Manfaat membayar uang keamanan jika ada Razia sudah terlebih dahulu diberikan informasi dari pihak oknum" (Pelaku usaha warung kopi 2).

"Jika ada razia ada pemberitahuan dari oknum aparat, iuran masuk pribadi bukan ke instansi" (Penjual minuman keras 2).

Berdasarkan pengakuan yang telah dijelaskan tersebut, diketahui bahwa terdapat oknum dari instansi berkaitan yang mengambil manfaat dari pelaku usaha underground economy untuk kepentingan pribadi. Kondisi demikian menunjukkan bahwa pelaku usaha underground economy seperti dalam penelitian ini adalah pelaku usaha toko kelontong, warung kopi, pedagang kaki lima, dan penjual minuman keras dipandang kurang memiliki kontribusi terhadap perekonomian regional, sehingga dimanfaatkan oleh oknum untuk keuntungan pribadi.

Apabila diperhatikan, kondisi para pelaku usaha underground economy di tengah kesulitan ekonomi akibat pandemi Covid-19 menunjukkan bahwa pelaku usaha tetap dapat bertahan, padahal pada kondisi yang lain beberapa pelaku usaha dalam skala besar dan legal banyak yang mengalami defisit. Hal ini diungkapkan dalam pernyataan berikut. 
"Selama wabah menggalami penurunan sepi pembeli, harga bahan baku naik dari supplier dan harga jual tetap" (Pedagang kaki lima 1).

"Pelaku usaha warkop ini juga menjual minuman keras secara sembunyi, pembelian barang dari daerah perbatasan dan juga menerima pesanan untuk pelanggan yang perlu minuman keras lain" (Pelaku usaha warung kopi 2).

"Seminggu bikin arak 2 kali tergantung permintaan, seminggu 200-300 kilo harga jual 25 ribu" (Penjual minuman keras 1).

Berdasarkan pernyataan tersebut dapat ditunjukkan bahwa para pelaku usaha underground economy tetap mampu bertahan untuk menjalankan usaha meskipun di tengah kondisi ekonomi sulit akibat pandemi Covid-19.

Secara keseluruhan hasil analisis kualitatif menunjukkan bahwa pelaku usaha underground economy memiliki potensi untuk dapat memberikan kontribusi dari sisi penerimaan pajak ketika usaha yang dilakukan telah terdaftar dalam otoritas pajak dan memiliki NPWP sehingga dapat mendukung perekonomian regional dari kabupaten yang termasuk 3T, salah satunya Kabupaten Bengkayang.

Hal ini mendukung hasil penelitian yang telah dilakukan oleh Rasbin, (2013) bahwa selama periode 2001 hingga 2013, underground economy menyumbang sebesar 8,33 persen dari PDB Indonesia untuk setiap triwulannya. Potensi pajak yang hilang juga cukup besar mencapai 1 persen dari nilai rata-rata PDB per triwulan.

\section{SIMPULAN}

Penelitian ini menghasilkan kesimpulan bahwa terdapat dua faktor yang mempengaruhi aktivitas underground economy yang ditandai dengan jumlah uang beredar dalam arti sempit (M1), jumlah potensi tindakan korupsi yang terjadi dalam instansi, dan besaran pajak penghasilan yang dipungut. Peningkatan pada jumlah tindak korupsi dalam instansi dapat menyebabkan peningkatan jumlah uang beredar (M1) sebagai konsekuensi untuk membiayai defisit sebagai dampak dari tindak korupsi yang dilakukan. Selain itu, peningkatan pada jumlah pajak penghasilan yang dipungut juga dapat meningkatkan jumlah uang beredar (M1).

Di Indonesia sendiri tindak korupsi yang terjadi mengalami peningkatan setiap tahun begitu juga pada jumlah pajak penghasilan yang dipungut, akibatnya jumlah uang beredar (M1), yang merupakan jumlah uang kartal yang dipegang masyarakat dan giro dalam mata uang rupiah mengalami peningkatan. Peningkatan uang yang dipegang masyarakat menandakan masyarakat memiliki peningkatan jumlah uang untuk melakukan aktivitas ekonomi, baik itu official economy maupun underground economy. Perlunya diterapkan sistem digital yang terintegrasi antara departemen pemerintah dan otoritas yang terkait dengan transaksi pembayaran baik dari pembayaran retribusi, pajak, transaksi bisnis, serta E-Government perlu diimplementasikan supaya akses masyarakat terhadap pemerintah lebih terbuka dengan diawasi lembaga khusus dengan berbasis integritas, akuntabilitas, akseleratif, repsonsif, dan keterbukaan. Hal tersebut bertujuan 
untuk meminimalkan potensi tindak suap, korupsi, dan pemungutan liar dengan dukungan pihak aparat keamanan yang bersih dan berpihak kepada masyarakat.

Berkaitan dengan underground economy, hasil penelitian menunjukkan bahwa pelaku usaha underground economy tidak memiliki NPWP yang berarti usaha yang dijalankan tidak terdaftar dalam otoritas pajak dan menimbulkan beban bagi pendapatan pajak pemerintah daerah. Alasan para pelaku usaha tidak mendaftarkan usaha secara legal adalah tidak memiliki pengetahuan, tidak merasa penting, dan pengurusan legalitas dalam otoritas pajak yang rumit. Akibatnya daerah tertinggal yang seharusnya memiliki potensi untuk menerima pendapatan dari aktivitas underground economy yang dilakukan oleh pelaku usaha justru menjadi beban. Oleh karena itu, penting bagi pemerintah pusat maupun daerah untuk dapat segera melakukan pendataan dan merumuskan program yang dapat mendorong pelaku usaha underground economy untuk menjalankan ekonomi secara legal dan masuk dalam aktivitas official economy. Dengan begitu pendapatan pajak regional wilayah 3T dapat mengalami peningkatan dan dapat mendukung pertumbuhan ekonomi regional dan nasional. Sosialisasi, pendampingan, dan pelatihan kepada masyarakat secara berkelanjutan mengenai informasi penting untuk mendukung pembangunan daerah. 


\section{DAFTAR PUSTAKA}

Afdi, M., \& Purnomo, K. (2015). underground economy activities in Indonesia. 65608. https://mpra.ub.uni-muenchen.de/65608/1/MPRA_paper_65608.pdf

Alamsyah, W., Abid, L., \& Sunaryanto, A. (2018). Laporan Tren Penindakan Kasus Korupsi Tahun 2018. Indonesia Corruption Watch (ICW), 1-33.

https://antikorupsi.org/sites/default/files/laporan_tren_penindakan_kasus_korupsi_2018.p df

Amoh, J. K., \& Adafula, B. (2019). An estimation of the underground economy and tax evasion: Empirical analysis from an emerging economy. Journal of Money Laundering Control, 22(4), 626-645. https://doi.org/10.1108/JMLC-01-2019-0002

Asaminew, E. (2010). The Underground Economy and Tax Evasion in Ethiopia: Implications for Tax Policy. Macroeconomic Division Ethiopian Economic Policy Research Institute, 1-26. http://www.csae.ox.ac.uk/conferences/2011-edia/papers/130-asaminew.pdf

Azwar, \& Mulyawan, andi wawan. (2017). Analisis Underground Economy Indonesia dan Potensi Penerimaan Pajak. Jurnal Info Artha, vol 1 no 1, 60-78.

Badulescu, A. (2011). The underground economy: What is the influence of the discount factor? African Journal of Business Management, 5(16), 7050-7054. https://doi.org/10.5897/AJBM11.1192

Basuki, A. T. (2017). Pengantar Ekonometrika. Danisa Media.

BBC Indonesia. (2013). Harga BBM mendorong inflasi Juni. Retrieved from https://www.bbc.com/indonesia/berita_indonesia/2013/07/130630_inflasi_bbm_juli

Creswell. (2014). Research Design : qualitative, quantitative and mixec methods approaches. SAGE Publications Inc.

Creswell, J. W. (2010). Research Design : John W. Creswell. In Research design : Qualitative,Quantitative and Mix Methods Approaches. (second edi). SAGE Publications Inc.

Departemen Statistik Bank Indonesia. (2019). Analisis Uang Beredar Desember 2019. 1-5. https://www.bi.go.id/id/publikasi/perkembangan/Pages/M2-November-2018.aspx

Faal, E. (2003). Currency Demand, the Underground Economy, and Tax Evasion: The Case of Guyana. IMF Working Papers, 03(7), 1. https://doi.org/10.5089/9781451842432.001

Fathul, L. (2014). Siaran Pers OJK Tetapkan Batas Atas Suku Bunga Dana Perbankan. Otoritas Jasa Keuangan, September, 1. Siaran Pers OJK Tetapkan Batas Atas Suku Bunga Dana Perbankan.html

Feige, E. L. (1990). Defining and estimating underground and informal economies: The new institutional economics approach. World Development, 18(7), 989-1002. https://doi.org/10.1016/0305-750X(90)90081-8

Furuoka, F., \& Munir, Q. (2014). Unemployment and Inflation in Malaysia: Evidence from Error Correction Model. Philippone Journal of Development, 1(1), 35-45.

Herlina wa ode, et. al. (2015). Strategi Pengembangan Usaha Sektor Informal dalam Meningkatkan Pendapatan Pedagang Kaki Lima di Kecamatan Kambu Kota Kendari. 125-134.

Kanao, Koji, H. dan, \& Shigeyuki. (2010). The size of the underground economy in Japan. Munich 
Personal RePec Archive, 24064.

Kementerian Keuangan Republik Indonesia. (2019). APBN Kita : Kinerja dan Fakta. In kementrian keuangan republik indonesia. https://www.kemenkeu.go.id/publikasi/apbn-kita/

Kiani, M., Ahmed, A., \& Zaman, K. (2015). Combining qualitative and quantitative approaches for measuring underground economy of Pakistan. Quality and Quantity, 49(1), 295-317. https://doi.org/10.1007/s11135-013-9987-1

Korupsi, K. P. (2019). Laporan Akuntabilitas Kinerja 2019. In KPK.go.id (Vol. 0, Issue 0, p. 2019). Komisi Pemberantasan Korupsi. https://doi.org/10.22201/fq.18708404e.2004.3.66178

Kristianto, A. H. (2019). Analyzing The Influence Of Interest Rates on Money Demand According to Keynesian Theory. Msdj Shanti Bhuana, 1(1), 38-47.

Kristianto, A. H., \& Nurchayo, A. C. (2020). Potret Kondisi Perekonomian Indonesia. Amerta Media.

Lawi, Gloria Fransisca Katharina. (2019). BI : Uang Beredar November 2019 Tercatat Menguat. Retrieved from https://finansial.bisnis.com/read/20200102/11/1186283/bi-uang-beredarnovember-2019-tercatat-menguat

Mazhar, U., \& Méon, P. G. (2017). Taxing the unobservable: The impact of the shadow economy on inflation and taxation. World Development, 90. https://doi.org/10.1016/j.worlddev.2016.08.019

Melnick, R., \& Sokoler, M. (1984). The Government Revenue From Money Creation and The Inflationary Effects of a Decline in The Rate of Growth of GNP. Journal of Monetary Economics, 13.

Musa, Y., Usman U., \& Zoramawa, A.B. (2014). Relationship between Money Supply and Government Revenues in Nigeria. CBN Journal of Applied Statistics, 5 (2), 117-136.

Nizar, M. A. (2015). Potensi penerimaan pajak dari underground economy di indonesia. Kajian Ekonomi Dan Keuangan, 15, 1-38. https://doi.org/1410-3249

Nurunnabi, M. (2019). Political Influence and Tax Evasion in Bangladesh: What Went Wrong? 26, 113-134. https://doi.org/10.1108/s1058-749720190000026007

Ouédraogo, I. M. (2017). Governance, Corruption, and the Informal Economy. Modern Economy, 08(02), 256-271. https://doi.org/10.4236/me.2017.82018

Ozsahin, S., \& Ucler, G. (2017). The consequences of corruption on inflation in developing countries: Evidence from panel cointegration and causality tests. Economies, 5(4). https://doi.org/10.3390/economies5040049

Pravasanti, Y. A. (2018). Dampak Kebijakan dan Keberhasilan Tax Amnesty bagi Perekonomian Indonesia. Kompartemen: Jurnal Ilmiah Akuntansi, 16(1), 84-94. https://doi.org/10.30595/kompartemen.v16i1.2415

Rahmani, T., \& Yousefi, H. (2010). Corruption, Monetary Policy, and Inflation: A Cross-Country Examination.

Rasbin. (2013). Ekspektasi Potensi Underground Economy di Indonesia. Kajian, 18(3), 229-239. https://doi.org/https://doi.org/10.22212/kajian.v18i3.493

Rothenberg, A. D., Gaduh, A., Burger, N. E., Chazali, C., Tjandraningsih, I., Radikun, R., Sutera, C., \& Weilant, S. (2016). Rethinking Indonesia's Informal Sector. World Development, 80, 96-113. 
https://doi.org/10.1016/j.worlddev.2015.11.005

Samimi, A. J., \& Abedini, M. (2012). Control of Corruption and Inflation Tax: New Evidence From Selected Developing Countries. Procedia - Social and Behavioral Sciences, 62, 441-445. https://doi.org/10.1016/j.sbspro.2012.09.072

Samuda, S. J. A. (2016). Underground Economy in Indonesia. Buletin Ekonomi Moneter Dan Perbankan, 19(1), 39-56. https://doi.org/10.21098/bemp.v19i1.599

Schneider, F., \& Hametner, B. (2014). The shadow economy in Colombia: Size and effects on economic growth. Peace Economics, Peace Science and Public Policy, 20(2), 293-325. https://doi.org/10.1515/peps-2013-0059

Tanzi, V., \& Fund, I. M. (2014). The Shadow Economy , Its Causes and Its Consequences. International Seminar on the Shadow Economy Index in Brazil," Brazilian Institute of Ethics in Competition, July.

Wardiyanto, Bintoro. (2009). Kebijakan Pengampunan Pajak (Tax Amnesty) [Perspektif Kerangka Kerja Implementasi Sunset Policy mendasarkan mendasarkan UU No 28 tahun 2007]. Jurnal Masyarakat Kebudayaan dan Politik, 21(4): 328-335.

Williams, C. C., \& Horodnic, I. A. (2017). Evaluating the relationship between social exclusion and participation in the informal sector in the European Union. International Journal of Manpower, 38(3), 489-503. https://doi.org/10.1108/IJM-10-2015-0179

Yakubu, M., Umar, U., \& Bello, Z. A. (2014). Relationship between money supply and government revenues in Nigeria. CBN Journal of Applied Statistics, 5(2), 117-136. 
LAMPIRAN

Tabel 5. Hasil Wawancara pertama (1)

\begin{tabular}{|c|c|c|c|c|c|c|c|c|}
\hline & TK1 & TK2 & PKL1 & PKL2 & WK1 & WK2 & MK1 & MK2 \\
\hline \multicolumn{9}{|l|}{ Profil } \\
\hline Pendidikan & SMP & SMP & SMP & SMP & SMA & SMA & SMA & SMA \\
\hline Lama usaha & 10 tahun & 5 tahun & 12 tahun & 10 tahun & 1 tahun & 2 tahun & 5 tahun & 8 tahun \\
\hline $\begin{array}{l}\text { Latar belakang } \\
\text { keluarga }\end{array}$ & Petani & $\begin{array}{l}\text { PNS, } \\
\text { mantri, } \\
\text { dan bidan }\end{array}$ & Pedagang & Pedagang & Aparat & Petani & Pedagang & Petani \\
\hline $\begin{array}{l}\text { Alasan membuka } \\
\text { usaha }\end{array}$ & $\begin{array}{l}\text { Keahlian } \\
\text { berdagang }\end{array}$ & $\begin{array}{l}\text { Tidak } \\
\text { mengangg } \\
\text { ur }\end{array}$ & $\begin{array}{l}\text { Menyambu } \\
\text { ng hidup }\end{array}$ & $\begin{array}{l}\text { menyambu } \\
\text { ng hidup }\end{array}$ & $\begin{array}{l}\text { Usaha } \\
\text { sampingan }\end{array}$ & $\begin{array}{l}\text { Menyam } \\
\text { bung } \\
\text { hidup } \\
\end{array}$ & $\begin{array}{l}\text { Usaha } \\
\text { sampingan }\end{array}$ & $\begin{array}{l}\text { Usaha } \\
\text { sampingan }\end{array}$ \\
\hline \multicolumn{9}{|l|}{ Jaminan Pekerja } \\
\hline Upah & $<\mathrm{UMR}$ & $<$ UMR & $\begin{array}{l}\text { > UMR } \\
(50 \mathrm{rb} \\
\text { hari) }\end{array}$ & $<\mathrm{UMR}$ & Ada & Ada & Ada & Ada \\
\hline Jaminan Sosial & Tidak ada & Tidak ada & Tidak ada & Tidak ada & Tidak ada & Tidak ada & Tidak ada & Tidak ada \\
\hline \multicolumn{9}{|l|}{ Perizinan } \\
\hline NPWP & Tidak ada & Tidak ada & Tidak ada & Tidak ada & Tidak ada & Tidak ada & Tidak ada & Tidak ada \\
\hline Izin Usaha & Tidak ada & Tidak ada & Tidak ada & Tidak ada & Tidak ada & Tidak ada & Tidak ada & Tidak ada \\
\hline \multicolumn{9}{|l|}{ Retribusi } \\
\hline Kebersihan & $\begin{array}{l}\text { Ada, } \\
20.000\end{array}$ & Ada & Tidak ada & Ada & Ada & Ada & Ada & Ada \\
\hline Keamanan & $\begin{array}{l}\text { Ada, } \\
30.000\end{array}$ & Ada & Tidak ada & Ada & Ada & Ada & Ada & Ada \\
\hline
\end{tabular}


Tabel 6. Hasil Wawancara kedua (2)

\begin{tabular}{|c|c|c|c|c|c|c|c|c|}
\hline Keterangan & TK1 & TK2 & PKL1 & PKL2 & WK1 & WK2 & MK1 & MK2 \\
\hline IURAN & $\begin{array}{l}\text { Pembayara } \\
\text { n retribusi } \\
\text { sampah / } \\
\text { kebersihan } \\
\text { tidak ada } \\
\text { perubahan } \\
\text {, hanya } \\
\text { sekedar } \\
\text { membayar } \\
\text { saja, } \\
\text { lingkungan } \\
\text { toko masih } \\
\text { kotor. } \\
\text { NPWP } \\
\text { tidak } \\
\text { begitu } \\
\text { penting, } \\
\text { retribusi } \\
\text { hanya } \\
\text { sekedar } \\
\text { formalitas. }\end{array}$ & $\begin{array}{l}\text { Tumpang } \\
\text { tindih } \\
\text { dalam } \\
\text { pembayara } \\
\mathrm{n} \text { iuran } \\
\text { beberapa } \\
\text { pelaku } \\
\text { ekonomi } \\
\text { luput dari } \\
\text { pembayara } \\
\text { n iuran } \\
\text { dibandingk } \\
\text { an pelaku } \\
\text { ekonomi } \\
\text { lain. }\end{array}$ & - & $\begin{array}{l}\text { Izin } \\
\text { berdasarkan } \\
\text { keanggotaan } \\
\text { APKL, } \\
\text { retribusi dan } \\
\text { iuran tidak } \\
\text { menentu } \\
\text { kadang } \\
\text { ditarik } \\
\text { kadang tidak, } \\
\text { ada peraturan } \\
\text { dalam APKL } \\
\text { namun pelaku } \\
\text { usaha tidak } \\
\text { memahami isi } \\
\text { dari pari } \\
\text { perundangan } \\
\text { tersebut.Pela } \\
\text { ku usaha } \\
\text { makanan } \\
\text { dibedakan } \\
\text { dengan usaha } \\
\text { warung kopi, } \\
\text { ditarik iuran } \\
\text { 10 \% dari } \\
\text { omset. }\end{array}$ & $\begin{array}{l}\text { Adapun iuran } \\
\text { yang di beri } \\
\text { adalah iuran } \\
\text { sukarela, } \\
\text { tanpa adanya } \\
\text { paksaan dari } \\
\text { pihak yang } \\
\text { bersangkutan } \\
\text { dan iuran } \\
\text { yang ung } \\
\text { diberikan } \\
\text { untuk pribadi } \\
\text { bukan untuk } \\
\text { dinas, biasa } \\
\text { pelaku usaha } \\
\text { memberikan } \\
\text { uang kang } \\
\text { keamanan } \\
\text { berkisar 200- } \\
\text { 300 ribu per } \\
\text { orang. } \\
\text { Pemberian } \\
\text { iuran tersebut } \\
\text { setiap bulan, } \\
\text { pihak } \\
\text { keamanan } \\
\text { yang datang } \\
\text { berkisar dua } \\
\text { sampai tiga } \\
\text { orang. }\end{array}$ & $\begin{array}{l}\text { Manfaat } \\
\text { membayar } \\
\text { uang } \\
\text { keamanan } \\
\text { jika ada } \\
\text { razia } \\
\text { sudah } \\
\text { terlebih } \\
\text { dahulu } \\
\text { diberikan } \\
\text { informasi } \\
\text { dari pihak } \\
\text { oknum. }\end{array}$ & $\begin{array}{l}\text { Uang } \\
\text { retribusi } \\
\text { dari aparat } \\
\text { sebagai } \\
\text { uang } \\
\text { keamanan. }\end{array}$ & $\begin{array}{l}\text { Jika ada razia } \\
\text { ada } \\
\text { pemberitahua } \\
\text { n dari oknum } \\
\text { aparat, iuran } \\
\text { masuk } \\
\text { pribadi bukan } \\
\text { ke instansi. }\end{array}$ \\
\hline
\end{tabular}


101 | Bina Ekonomi

\begin{tabular}{|c|c|c|c|c|c|c|c|c|}
\hline Keterangan & TK1 & TK2 & PKL1 & PKL2 & WK1 & WK2 & MK1 & MK2 \\
\hline PERIZINAN & $\begin{array}{l}\text { Tidak ada } \\
\text { sosialisasi } \\
\text { masalah } \\
\text { NPWP dan } \\
\text { izin usaha } \\
\text { dari } \\
\text { pemerinta } \\
\text { h - perlu } \\
\text { adanya } \\
\text { sosialisasi } \\
\text { terkait } \\
\text { NPWP dan } \\
\text { Izin Usaha } \\
\text { serta } \\
\text { manfaat dr } \\
\text { pajak } \\
\text { tersebut } \\
\text { dan } \\
\text { pemahama } \\
\text { n } \\
\text { mengenai } \\
\text { NPWP }\end{array}$ & $\begin{array}{l}\text { Npwp } \\
\text { dirasa } \\
\text { tidak perlu } \\
\text { atau } \\
\text { dibutuhkan } \\
\text { ' karena } \\
\text { tidak ada } \\
\text { manfaat } \\
\text { dan selama } \\
\text { ini merasa } \\
\text { usaha } \\
\text { melanggar } \\
\text { hukum, } \\
\text { usaha tidak } \\
\text { tetap } \\
\text { (berpindah } \\
\text { ). }\end{array}$ & $\begin{array}{l}\text { NPWP } \\
\text { Tidak } \\
\text { begitu } \\
\text { penting } \\
\text { dan } \\
\text { bermanfaa } \\
t \text { menurut } \\
\text { ybs. }\end{array}$ & - & $\begin{array}{l}\text { NPWP dan izin } \\
\text { usaha tidak } \\
\text { diperlukan } \\
\text { karena } \\
\text { merasa usaha } \\
\text { kecil dan tidak } \\
\text { diperhitungka } \\
\text { n, merupakan } \\
\text { usaha } \\
\text { sampingan } \\
\text { aparat dan } \\
\text { anggota } \\
\text { dewan. }\end{array}$ & $\begin{array}{l}\text { Izin usaha } \\
\text { tidak ada } \\
\text { karena } \\
\text { dirasa } \\
\text { rumit dan } \\
\text { birokrasi } \\
\text { dalam } \\
\text { pengurusa } \\
\text { n panjang. }\end{array}$ & - & - \\
\hline $\begin{array}{l}\text { KONDISI } \\
\text { USAHA }\end{array}$ & $\begin{array}{l}\text { Disaat } \\
\text { wabah } \\
\text { COVID } 19 \\
\text { menggala } \\
\text { mi } \\
\text { penurunan } \\
\text { penjualan, } \\
\text { dari pihak } \\
\text { supplier } \\
\text { menggala } \\
\text { mi } \\
\text { penurunan }\end{array}$ & - & $\begin{array}{l}\text { Selama } \\
\text { wabah } \\
\text { menggala } \\
\text { mi } \\
\text { penurunan } \\
\text { sepi } \\
\text { pembeli, } \\
\text { harga } \\
\text { bahan } \\
\text { baku naik } \\
\text { dari } \\
\text { supplier }\end{array}$ & $\begin{array}{l}\text { Penurunan } \\
\text { penjualan } \\
\text { selama wabah } \\
\text { COVID 19, } \\
\text { sepi pembeli, } \\
\text { harga dari } \\
\text { supplier } \\
\text { menggalami } \\
\text { kenaikan, } \\
\text { harga jual } \\
\text { tetap. }\end{array}$ & - & $\begin{array}{l}\text { Pelaku } \\
\text { usaha } \\
\text { warkop ini } \\
\text { juga } \\
\text { menjual } \\
\text { minuman } \\
\text { keras } \\
\text { secara } \\
\text { sembunyi, } \\
\text { pembelian } \\
\text { barang } \\
\text { dari }\end{array}$ & $\begin{array}{l}\text { Seminggu } \\
\text { bikin arak } \\
2 \quad \text { kali } \\
\text { tergantung } \\
\text { permintaa } \\
\text { n, } \\
\text { seminggu } \\
200-300 \\
\text { kilo harga } \\
\text { jual } 25 \\
\text { ribu. }\end{array}$ & $\begin{array}{l}\text { Sebulan } 1-2 \\
\text { kali orang } \\
\text { datang untuk } \\
\text { dijual } \\
\text { kembali. }\end{array}$ \\
\hline
\end{tabular}


Volume 23 No 2 Tahun 2019| 102

\begin{tabular}{|c|c|c|c|c|c|c|c|c|}
\hline Keterangan & TK1 & TK2 & PKL1 & PKL2 & WK1 & WK2 & MK1 & MK2 \\
\hline & $\begin{array}{l}\text { jika ada } \\
\text { pun harga } \\
\text { naik. }\end{array}$ & & $\begin{array}{l}\text { dan harga } \\
\text { jual tetap. }\end{array}$ & & & $\begin{array}{l}\text { daerah } \\
\text { perbatasa } \\
\text { n dan juga } \\
\text { menerima } \\
\text { pesanan } \\
\text { untuk } \\
\text { pelanggan } \\
\text { yang perlu } \\
\text { minuman } \\
\text { keras lain }\end{array}$ & & \\
\hline
\end{tabular}

